\title{
On Knowing Greek (and Latin): Classical Elements in the Poetry of Stevie Smith
}

\section{DEMMY VERBEKE}

(C) Springer Science+Business Media B.V. 2009

This article discusses the influence of the ancient world and its literature on the poetry of Stevie Smith (1902-1971). I examine the three ways in which Smith incorporates classical elements in her poetical work: 1) the use of Latin phrases and antique settings, 2) adaptations of Greek mythology and 3) translations of classical Latin texts. Through an attentive reading of representative poems, I discuss her non-conformistic way of dealing with the classics and show how genuine admiration and clever use of the classics hide under the cover of her playful tone and apparent artlessness.

7 he publication of Novel on Yellow Paper in 1936 made its author, Stevie Smith, an overnight sensation. The book was so well received that the poet Richard Nichols wrote a long letter to Virginia Woolf, assuming that she was the true author and congratulating her upon her best work so far. ${ }^{1}$ Soon it became clear that the debutante Florence Margaret Smith (19021971), and not Virginia Woolf, had written the novel; but that did not deter people like Clive Bell, Noel Coward, and, later, Sylvia Plath from declaring themselves admirers of her unique literary talent.

The novels of Florence Margaret Smith, who published under the pseudonym Stevie Smith, enjoyed several reprints, even until the 1990's, but their

* I wish to thank the editor of this journal, Wolfgang Haase, and Els Degryse, whose valuable comments helped shape this article.

1. This anecdote is related in Jack Barbera - William McBrien (eds.), Me Again, Uncollected Writings of Stevie Smith (London: Virago, 19885), p. 6.

Demmy Verbeke, Katholieke Universiteit Leuven, De Wulf-Mansion Centre for Ancient, Medieval and Renaissance Philosophy, Kardinaal Mercierplein 2 - bus 3200, 3000 Leuven, BELGIUM

International Journal of the Classical Tradition, Vol. 16, No. 3/4, September/December 2009, pp. 467-483. 
author is nowadays best remembered as a highly original poet, through several editions of her Collected Poems (first published in 1975) and her most celebrated piece "Not Waving but Drowning". This renown even increased after her death. In March 1977, Stevie: A Play, written by Hugh Whitemore, was first performed in London and would lead to the movie Stevie, starring Glenda Jackson in the title role, the following year. The interest in her life and work resulted in two biographies, published in $1985^{2}$ and $1989^{3}$, and several academic publications such as Catherine Civello's Patterns of Ambivalence. The Fiction and Poetry of Stevie Smith (1997), Laura Severin's Stevie Smith's Resistant Antics (1997) and Romana Huk's Stevie Smith: Between the Lines (2005).

Several critics of the work of Stevie Smith have noted the allusive nature of her writing and Smith's tendency to mingle traditional elements with modern ones. Hermione Lee, for example, argued that she belonged to a generation whose mind was a "rag-bag of quotations" taken from the traditional English poets, the Bible and the classics. ${ }^{4}$ Nonetheless, few of the critics seem interested in exploring the presence of classical elements in her poetical work beyond mentioning the occurrence of a name or fact from the ancient world. Noteworthy exceptions are the analysis by Anne Mounic of the presence of Hermes and Persephone ${ }^{5}$ and the parallel drawn by Calvin Bedient between Smith's Collected Poems and the oeuvre of Horace. Bedient argues that her poetry is characterized by comparable density and a similar free, inventive and comical way of dealing with the truth. Her verses, like those of the Roman poet, are dominated by common sense and creative pleasure. However, she would still, according to Bedient, scandalize Horace with her non-conformism, regardless of theme, emotionality or poetical skills. He sees Smith as a true classic, not because of her use of antique material, but because of her way of thinking and writing: "Crowd her into a word and she is classical". 6

Many questions on the poetical use of the classics in Smith's work remain unanswered. What makes Smith a classical poet and how do the classics become part of her typical style, which has been described as playful, eccentric, quirky and irreverent? ${ }^{7}$ And what is the origin of her fascination with the ancient world?

2. Jack Barbera - William McBrien, Stevie. A Biography of Stevie Smith (London: Heinemann, 1985).

3. Frances Spalding, Stevie Smith. A Biography (New York - London: W. W. Norton \& Company, 1989).

4. Hermione Lee, 'Introduction' to Stevie Smith. A Selection, Edited by Hermione Lee (London - Boston: Faber and Faber, 1983, p. 24). See also Romana Huk, Stevie Smith: Between the Lines (Basingstoke - New York: Palgrave Macmillan, 2005), p. 19; James Najarian, 'Contributions to Almighty Truth: Stevie Smith's Seditious Romanticism', Twentieth-Century Literature 49 (2003), pp. 472-493; Barbera - McBrien, Stevie. A Biography of Stevie Smith (above, n. 2), pp. 96-97 and pp. 166-167; and Spalding, Stevie Smith. A Biography (above, n. 3), passim.

5. Anne Mounic, Les tribulations de Perséphone: Poésie, autre, au-delà (Kathleen Raine, Stevie Smith, Veronica Forrest-Thomson) (Paris: L'Harmattan, 2002), passim.

6. Calvin Bedient, 'Horace and Modernism', in Sanford Sternlicht (ed.), In Search of Stevie Smith (Syracuse: Syracuse University Press, 1991), pp. 166-168; quote on p. 168.

7. See, amongst others, Huk, Stevie Smith: Between the Lines (above, n. 4), p. 1. 
Smith became acquainted with the classics at school. She indicates that she had to read the Georgics of Virgil and had to memorize "the whole of Horace". ${ }^{8}$ And although she never took any classes in Greek, she did participate in a school production of Euripides' Bacchae in the original language around 1920. However, Smith also learned the classics in a less amusing way. There was a severe system of "signatures" at North London Collegiate School for Girls, where Smith was a student from 1917 till 1920. Any pupil who misbehaved in one way or another had to note down in a book what she had done and sign the remark. Certain of these "sigs" were accompanied by a punishment like learning a Latin poem by heart. ${ }^{\circ}$

After her school education and a six-month course at Mrs Hoster's Secretarial Training College in London, Smith became a secretary. She soon grew to dislike her job, but kept it until her suicide attempt on 1 July 1953, after which she received a small pension. Financial difficulties before and after her attempt forced her to earn some extra money as a book reviewer for periodicals such as The Daily Telegraph, The Tribune, Modern Woman, The Observer, Aeronautics and Spectator. As a reviewer, she preferred books on history, religion and mythology, which would prove to be a source of inspiration for her literary work. ${ }^{10}$ The selection made by Jack Barbera and William McBrien ${ }^{11}$ does not contain a single review of a scholarly book on antiquity, or translations or editions of classical authors, and it is indeed doubtful, judging by the periodicals for which she wrote, that many such publications would have come her way for review.

But the classics did play an integral role in Smith's personal life. In times of sickness or distress, she turned to the Greeks and Romans, much in the same way as Virginia Woolf, whose appraisal Smith copied in one of her notebooks: "and it is to the Greeks that we turn when we are sick of the vagueness, of the confusion, of the Christianity and its consolations, of our own age". ${ }^{12}$ Consequently, there is a clear parallel between Smith's interest in the classics on the one hand and her troubled relationship with the concept of death on the other. $^{13}$

8. Barbera - McBrien (eds.), Me Again, Uncollected Writings of Stevie Smith (above, n. 1), respectively p. 282 and pp. 90-91.

9. You can find Smith's own version of the story in "At School" (cf. Barbera - McBrien [eds.], Me Again, Uncollected Writings of Stevie Smith [above, n.1], p. 119). See also Spalding, Stevie Smith. A Biography (above, n. 3), p. 28. In one instance, the young Stevie Smith had to learn the Sirmio-poem of Catullus (carm. 31), of which she would later write a "recollection" (which I discuss in this paper [below, p. $478 \mathrm{f}$.]).

10. Stevie Smith confirmed this in an interview with Jonathan Williams. Cf. Sternlicht (ed.), In Search of Stevie Smith (above, n. 6), p. 43. See also Barbera - McBrien (eds.), Me Again, Uncollected Writings of Stevie Smith (above, n. 1), pp. 8-9 and Huk, Stevie Smith: Between the Lines (above, n. 4), p. 19.

11. Barbera - McBrien (eds.), Me Again, Uncollected Writings of Stevie Smith (above, $\mathrm{n}$. 1), pp. 173-209.

12. Spalding, Stevie Smith. A Biography (above, n. 3), p. 250. The quote stems from Woolfe's essay On not knowing Greek.

13. Smith's poetry on death is discussed in Els Degryse, Finding a Way out of Life, Stevie Smith's Poetry on Death and Religion (Katholieke Universiteit Leuven, MA Thesis, 2001), but the author failed to notice almost all classical allusions in these poems. 
Exemplary of the combination of death and the classics is her adaptation of Greek myths. The god Hermes, for instance, illustrates for her the connection between the world of the living and the world of the dead. ${ }^{14}$ He appears as the character Pompey Casmilus in her first two novels and is recurrent in her poetry, e.g. in "The Ambassador"15.

The Ambassador

... known also among the Phoenicians as Casmilus (Lemprière) ${ }^{16}$

Underneath the broad hat is the face of the Ambassador

He rides on a white horse through hell looking two ways.

Doors open before him and shut when he has passed.

$\mathrm{He}$ is master of the mysteries and in the market place

He is known. He stole the trident, the girdle,

The sword, the sceptre and many mechanical instruments.

Thieves honour him. In the underworld he rides carelessly.

Sometimes he rises into the air and flies silently.

Another example is the poem "Persephone", in which Smith retells the story seen through the eyes of Persephone and reveals that she brought about her own kidnapping. In this way, Smith turns the original myth upside-down. The reason why Persephone desired to go to the underworld is given in the last lines of the poem:

Does my husband the King know, does he guess

In this wintriness

Is my happiness?

She prefers the world of death, because that is where her happiness lies. Even Persephone's grief over her mother's desperation is not stronger than her love of death. ${ }^{17}$

These examples illustrate that there is a whole range of ways in which Smith made use of classical elements in her work. A closer look at her poetical oeuvre shows that her treatment of classical material is in line with what other critics have called the tragicomical, original and fausse-naïve nature of

14. See Els Degryse - Demmy Verbeke, 'De oudheid volgens Stevie Smith', Kleio. Tijdschrift voor oude talen en antieke cultuur, 34 (2005), pp. 96-114 (especially pp. 106107) and Mounic, Les tribulations de Perséphone, pp. 79-84 and p. 254.

15. All poems by Stevie Smith are quoted from The Collected Poems of Stevie Smith (London: Allen Lane, 19782), unless otherwise indicated.

16. This subtitle appears only in Stevie Smith. A Selection (and not in the Collected Poems). "Lemprière" is John Lemprière (1765-1824), whose Bibliotheca Classica or Classical Dictionary (first published in 1788) acted as a standard reference work for Greco-Roman mythology in the English-speaking world until the $20^{\text {th }}$ century. Smith's use of "Casmilus" instead of the correct "Camillus" is based on a printing error in her copy of the 1832 edition of Lemprière's dictionary.

17. Stevie Smith in a BBC-radio broadcasting from 1966: "She [Persephone] loves her [mother], but at the same time, she does not want to be sought for all the time, and wept for, and begged to come home. She wants to be herself, and free to stretch out and take her time" (quoted by Barbera - McBrien, Stevie. A Biography of Stevie Smith [above, n. 2], p. 167). 
her work. ${ }^{18}$ I will illustrate this point through a selective discussion of her use of ancient language and settings, her more elaborate adaptations of Greek mythology, and her "translations" of classical poems.

At times, Smith makes obvious allusions to the classical world through her choice of a Latin title or her use of Latin words and expressions. As straightforward and simplistic as this may seem, the reality of the poem's relationship with the classical language is often more complex. This is illustrated by the poem "Sunt Leones":

\section{Sunt Leones}

The lions who ate the Christians on the sands of the arena

By indulging native appetites played what has now been seen a

Not entirely negligible part

In consolidating at the very start

The position of the Early Christian Church.

Initiatory rites are always bloody

And the lions, it appears

From contemporary art, made a study

Of dyeing Coliseum sands a ruddy

Liturgically sacrificial hue

And if the Christians felt a little blue -

Well people being eaten often do.

Theirs was the death, and theirs the crown undying,

A state of things which must be satisfying.

My point which up to this has been obscured

Is that it was the lions who procured

By chewing blood gristle flesh and bone

The martyrdoms on which the Church has grown;

I only write this poem because I thought it rather looked

As if the part the lions played was being overlooked.

By lions' jaws great benefits and blessings were begotten

And so our debt to Lionhood must never be forgotten.

The Latin title "Sunt Leones" ("There are lions") immediately pulls us into the classical world: we are placed in the Colosseum to watch Christians being eaten alive by lions. But the use of Latin can also be read as part of her critique on the Roman Catholic Church (as it is the official language of the Vatican), against which Smith's sarcasm is directed here. This sarcasm permeates the entire poem, irreverently stressing the important and overlooked role of the lions in the "Early Christian Church", and culminates in the lines "And if the Christians felt a little blue - / Well people being eaten often do". The poem ends in an elevation of the animals to almost religious heights: "our debt to Lionhood must never be forgotten". This conclusion was already anticipated by the title in Latin, traditionally the language used in rituals, inscriptions and official laudatory documents.

The poet returns to her criticism of the Church and its insistence on martyrdom in a poem which appeared thirteen years later. The setting is the same, but this time Smith makes her point in a very direct way. The subtleties of

18. Cf. Huk, Stevie Smith: Between the Lines (above, n. 4), p. 1. 
"Sunt Leones" (of which the Latin title was one) are gone and it is the martyr himself who speaks:

The Roman Road

A Christian speaks to a Lion in the Arena.

Oh Lion in a peculiar guise,

Sharp Roman road to Paradise,

Come eat me up, I'll pay thy toll

With all my flesh, and keep my soul.

I turn to another poem where Smith again uses a Latin title to call up a classical context, which is confirmed in the first line.

\section{Exeat}

I remember the Roman Emperor, one of the cruellest of them, Who used to visit for pleasure his poor prisoners cramped in dungeons,

So then they would beg him for death, and then he would say:

Oh no, oh no, we are not yet friends enough.

He meant they were not yet friends enough for him to give them death.

Unlike in "Sunt Leones" and "The Roman Road", Smith here does not combine the Latin language with the antique context in order to criticize Christianity. Instead, she re-uses the title throughout her poem in order to clarify the theme, namely the right to commit suicide. Her point is that we have to deserve death before it can be given to us or before we have the right to choose death ourselves. ${ }^{19}$ Smith is probably playing with a secular use of the word "exeat", being "a permission from a college or boarding school for temporary absence" ${ }^{20}$ This permission-idea is found in the poem itself through repetition of "we are not yet friends enough" (lines 4 and 5). The Roman emperor has to be friends with the prisoners in order to give them death, in order to let them go. The poem continues with a comparison of the state of the prisoners with the poet's state of being:

So I fancy my Muse says, when I wish to die:

Oh no, oh no, we are not yet friends enough,

And Virtue also says:

We are not friends enough.

The idea is voiced two times through "We are not (yet) friends enough" (lines 7 and 9). In the second half of the poem the idea is placed more and more in the forefront by a reformulation of "We are not yet friends enough" into "He is always putting her off until tomorrow" (v. 13), until the idea finally turns real.

19. See also her poem "Study to Deserve Death" (The Collected Poems of Stevie Smith [above, n. 15], p. 185).

20. Judy Pearsall (ed.), The Concise Oxford Dictionary (Oxford: Oxford University Press, $1999^{10}$ ), s.v. "exeat" (p. 497). 
... Life comes to him with love and says:

We are friends enough now for me to give you death;

Then he may commit suicide, then

He may go.

First, the positive version of the sentence is repeated and extended ("We are friends enough now for me to give you death"), then it is explained in a very straightforward way ("Then he may commit suicide"), and finally it is put in the most simplified and clearest way ("He may go"). The strength of this poem lies in its dramatical irony. As the title holds the clue, and is at the same time the last line of the poem (in translation), it has been clear from the beginning what this poem is about. Nonetheless, we have to find our way through repetition after repetition in order to come to that final answer, which was already incorporated in the very beginning, just as death is already certain for us from birth.

The poem "Magna est Veritas" is similar to "Exeat" in the sense that it also ends with a play on the title. But in contrast to "Sunt Leones" and "Exeat", the play does not extend to the whole poem.

\section{Magna est Veritas}

With my looks I am bound to look simple or fast I would rather look simple

So I wear a tall hat on the back of my head that is rather a temple

And I walk rather queerly and comb my long hair

And people say, Don't bother about her.

So in my time I have picked up a good many facts,

Rather more than the people do who wear smart hats

And I do not deceive because I am rather simple too

And although I collect facts I do not always know what they amount to.

I regard them as a contribution to almighty Truth, magna est veritas et praevalebit,

Agreeing with that Latin writer, Great is Truth and will prevail in a bit.

The sentence "Magna est veritas et praevalet" appears in an apocryphal biblical text (3 Esr. 4, 41), but it is unlikely that Smith was familiar with the original. She probably found inspiration in Thomas Brooks' The Crown and Glory of Christianity (1662) where one reads:

For (magna est veritas et praevalebit) great is truth and shall prevail. $^{21}$

This line might have set off the poem and given Smith the opportunity to end on a comical rhyme. Her last line echoes the Latin future tense, but humorously undermines its seriousness with the colloquial English phrase "in a bit". That instance aside, the rest of the poem has nothing to do with the ancient world. It is one of those poems that are exemplary for the idiosyncratic posi-

21. I owe this reference to Hermione Lee (Stevie Smith, A Selection [above, n. 4], p. 210). 
tion the poet Stevie Smith takes in the history of English literature or as Christopher Ricks said: "these [particularities] constitute the art of a poem which will not let on how artless or artful it is being." 22

Another example of the use of Latin words for comical effect is the curious "Tenuous and Precarious". Apparently, the poem was the result of a discussion Smith once had at a tea party. On that occasion, someone brought up some Latin words and out of the blue Smith started to make up a poem: "Stevie just made it up as she went along, almost like a conversation. It was easy but erudite." ${ }^{23}$ The female I-person in the poem (with the ominous name Finis) enumerates all the characters in her life. All these (male) figures are called Romans and bear a name ending in "-ous", a phonetic reminder of the masculine forms of Latin adjectives ending in $-u s(-a,-u m)$. Not all of these English adjectives-made-names with a Latin sounding ending have a genuine Latin equivalent. Precarious, Spurious, Posthumous do correspond with 'precarius', 'spurius', and 'postumus'; but the Latin equivalents for Tenuous, Perfidious, Surreptitious and Tedious are 'tenuis', 'perfidus', 'surrepticius' and 'taediosus', while Hazardous goes back to an Arabic rather than a Latin word. These names, in fact, all denominate a negative characteristic (weakness, infidelity, tediousness, etc.). The I-person makes it clear that all these characters / characteristics are now in the past, with the exception of the cat Tedious, and aptly finishes the poem with her own name:

\section{Tenuous and Precarious}

Tenuous and Precarious

Were my guardians,

Precarious and Tenuous,

Two Romans.

My father was Hazardous,

Hazardous,

Dear old man,

Three Romans.

There was my brother Spurious,

Spurious Posthumous,

Spurious was spurious

Was four Romans.

My husband was Perfidious,

He was perfidious,

Five Romans.

Surreptitious, our son,

Was surreptitious,

22. Christopher Ricks, 'Stevie Smith: "Great is truth and will prevail in a bit"', Grand Street, 1 (1981), pp. 147-157, quote on p. 150. Another reading of this poem is found in Najarian, 'Contributions to Almighty Truth: Stevie Smith's Seditious Romanticism' (above, n. 4), pp. 477-481 (but do note the factual errors in Najarian's text: the quote stems from Thomas, not Edmund Brooks, and the Latin text reads 'praevalet', not 'praelevet').

23. Barbera - McBrien, Stevie. A Biography of Stevie Smith (above, n. 2), p. 258. 
He was six Romans.

Our cat Tedious

Still lives,

Count not Tedious

Yet.

My name is Finis,

Finis, Finis,

I am Finis,

Six, five, four, three, two,

One Roman,

Finis.

The analysis of Smith's use of Latin words or phrases makes it clear that the Latin gives structure to the poem and can act as a technique to better illustrate her point (see, e.g., the analysis of "Sunt Leones" and "Exeat"). At the same time, Smith makes these classical elements her own, and reaches a comical, absurd or ironic effect through their use (most noteworthy in "Tenuous and Precarious"). This characteristic is likewise illustrated by her tendency to mingle different voices in her poems. When Smith uses a story line, an expression or a word from the classics, these voices are drawn into the poem and often interact with modern elements. That Smith aimed at this intertextuality is best shown through the poem "I had a dream...", which begins with the following verses:

I had a dream I was Helen of Troy

In looks, age and circumstances,

But otherwise I was myself.

The mixture of voices happens on two levels. First, there is the intertextuality of a twentieth century poet who starts a dialogue with former versions of the Helen legend. ${ }^{24}$ In the best known version (found in Homer, Virgil and others), Paris elopes with Helen to Troy, which sets off the Trojan war. Helen loves Paris, marries him and stays in Troy until her first husband, Menelaus, takes her back home. But a different tradition, starting from Stesichorus, defends Helen. The defense argues that Paris escaped to Troy with an "eidolon" (a wraith, phantom) of Helen and that the real Helen, in all her innocence, sojourned in Egypt for the duration of the war. ${ }^{25}$ Smith points explicitly at these different versions of the Helen-legend:

24. See Andrew L. Brown, art. 'Helen', in Simon Hornblower - Anthony Spawforth (eds.), The Oxford Classical Dictionary (Oxford - New York: Oxford University Press, 19963), p. 675; Ruth E. Harder, art. 'Helene', in Hubert Cancik - Helmuth Schneider (eds.), Der Neue Pauly. Enzyklopädie der Antike, Band 5: Gru-Iug (Stuttgart - Weimar: J. B. Metzler, 1998), col. 278-280; Robert Emmet Meagher, Helen. Myth, Legend and the Culture of Misogyny (New York: Continuum, 1995) and Bettany Hughes, Helen of Troy: Goddess, Princess, Whore (London: Jonathan Cape, 2005).

25. Stesichorus, fr. 192 (cf. Greek Lyric III: Stesichorus, Ibycus, Simonides, and others, ed. / trans. David A. Campbell, The Loeb Classical Library 144 (Cambridge - London: Harvard University Press, 1991], pp. 92-96). Smith probably learned the alternative version from Euripides' Helen. For a discussion of these different Helen 


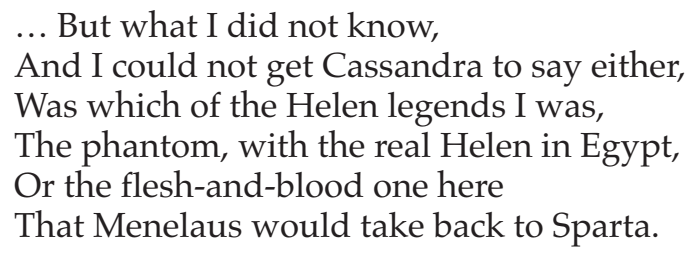

On a second level, the I-person in the poem dreams that she is Helen, walking on the Trojan walls and talking to other mythological characters, but also questioning her identity and commenting on the war (by comparing the continuous, meaningless battle over Troy with the First World War and speaking of the literary tradition which has developed around the Trojan myth). In this way, the I-person distances herself from the Helen-person and acts as if she were Helen and the omniscient twentieth century commentator of the myth at the same time. This double identity of the I-person thus reflects the two identities of Helen: the flesh-and-blood Helen and the phantom Helen.

The mixture between classical and modern elements also allows the poet to give ironic comments on the mythological characters. Cassandra, for example, is supposed to be able to foresee the future whereas the Helen in Smith's poem describes her as: "It was those peculiar eyes she had / As if she were short-sighted". This remark is not meaningless: on the one hand, it seems a witty contradiction to the divinatory capacities, which were - as every educated reader of Smith's poem knew - traditionally ascribed to Cassandra; but on the other hand it possibly alludes to that other famous prophet in Greek mythology, namely Tiresias, who was blinded, but received his prophetic gift as compensation. A few lines further, Smith's Helen openly questions Cassandra's prophetic talents:

I suppose you know how it's going to end, I said,

As well as I do? Dreams, dreams? They aren't dreams

You know. Do you know?

Near the end of the poem we reach the climax of the ironic use of the Cassandra-figure when Helen herself predicts Cassandra's end: "go along and finish up on Clytemnestra's sword-point".

Smith's treatment of mythology makes it clear that she is not hindered by too much reverence for the classical material and really makes it her own. The same characteristic is discernible in her engagement with the classics on a different level, namely in her renditions of classical poetry.

A first example is the poem Dido's Farewell to Aeneas, presented by Smith as a translation from Virgil:

Dido's Farewell to Aeneas

From Virgil.

I have lived and followed my fate without flinching, followed it gladly

And now, not wholly unknown, I come to the end.

stories, see John D. B. Hamilton, The Characterization and Function of Helen in Euripidean Drama (PhD diss. University of Minnesota, 1973). 
I built this famous city, I saw the walls rise,

As for my abominable brother, I don't think I've been too lenient.

Was I happy? Yes, at a price, I might have been happier

If our Dardanian Sailor had condescended to put in elsewhere.

Now she fell silent, turning her face to the pillow,

Then getting up quickly, the dagger in her hand,

I die unavenged, she cried, but I die as I choose,

Come Death, you know you must come when you're called

Although you're a god. And this way, and this way, I call you.

Readers familiar with the original passage in the fourth book of Virgil's Aeneid are no doubt surprised by the omission of the famous first lines of Dido's monologue: "Dulces exuviae, dum fata deusque sinebat, / Accipite hanc animam meque his exsolvite curis" (Aen. 4. 651-652: "O relics once dear, while God and Fate allowed, take my spirit, and release me from my woes!" $\left.{ }^{26}\right)$. Even more surprising are the last verses of Smith's "translation". The original conclusion of the speech reads (Aen. 4, 659-662):

Dixit, et os impressa toro: "Moriemur inultae!

Sed moriamur," ait. "Sic, sic iuvat ire sub umbras.

Hauriat hunc oculis ignem crudelis ab alto

Dardanus, et nostrae secum ferat omina mortis."

She spoke, and burying her face in the couch, "I shall die unavenged," she cries, "but let me die! Thus, thus I go gladly into the dark! Let the cruel Dardan's eyes drink in this fire from the deep, and carry with him the omen of my death!"

It is clear that Smith's version does not at all correspond with Virgil's text. The reference to Aeneas is replaced by an invocation of Death. Although this invocation is an addition of Smith, its phrasing alludes to the original: the repetition in Aen. 4, 660 ("Sic, sic iuvat ire sub umbras") returns in Smith's "And this way, and this way, I call you".

In her essay Too Tired for Words ${ }^{27}$, Smith explained that this adaptation of Virgil was again elicited by her fascination with death and that she had altered the final verses of Dido's monologue to strengthen this personal element:

"I remember once when I was feeling too tired to write an original poem I fell to translating Dido's Farewell to Aeneas, putting something into the last two lines that is not quite in Virgil, to express this proud thought of commanding the great god Thanatos (you remember she is stabbing herself) ... Yes, that thought of Death at command is a great relief to the tired."

26. This and the following translation taken from H. Rushton Fairclough, in Virgil. Eclogues, Georgics, Aeneid I-VI, with an English translation by H. Rushton Fairclough, revised by G. P. Goold, The Loeb Classical Library 63 (Cambridge - London: Harvard University Press, 1999), p. 467.

27. Cf. Barbera - McBrien (eds.), Me Again. Uncollected Writings of Stevie Smith (above, n. 1), pp. 111-118, quote on p. 112. 
Stevie Smith also turned to Catullus for inspiration. It is probably in imitation of Alfred Tennyson - whose work she greatly admired - that she wrote the poem Hendecasyllables (repeating the metric experiments of the Roman poet) and composed a "recollection" of Catullus $31^{28}$ :

Dear Little Sirmio

Catullus recollected

Dear little Sirmio

Of all capes and islands

Wherever Neptune rides the coastal waters and the open sea

You really are the nicest.

How glad I am to see you again, how fondly I look at you.

No sooner had I left Bithynia - and what was the name of the other place?

And was safely at sea

I thought only of seeing you.

Really is anything nicer

After working hard and being thoroughly worried

Than to leave it all behind and set out for home

Dear old home and one's own comfortable bed?

Even if one wears oneself out paying for them.

Of which the original reads:

Paene insularum, Sirmio, insularumque

ocelle, quascumque in liquentibus stagnis

marique vasto fert uterque Neptunus,

quam te libenter quamque laetus te inviso,

vix mi ipse credens Thyniam atque Bithynos

liquisse campos et videre te in tuto.

O quid solutis est beatius curis,

cum mens onus reponit ac peregrino

labore fessi venimus larem ad nostrum

desideratoque acquiescimus lecto?

Hoc est, quod unum est pro laboribus tantis.

Salve, o venusta Sirmio, atque ero gaude

gaudente; vosque, o Lydiae lacus undae,

ridete quicquid est domi cachinnorum.

Sirmio, bright eye of peninsulas and islands, all that in liquid lakes or vast ocean either Neptune bears: how willingly and with what joy I revisit you, scarcely trusting myself that I have left Thynia and the Bithynian plains, and that I see you in safety. Ah, what is more

28. Alfred Tennyson did the same in his Hendecasyllabics and Frater Ave atque Vale (in which he combined Catullus 31 and Catullus 101). Cf. The Poems of Tennyson in three volumes, second edition incorporating the Trinity College Manuscripts, ed. Christopher Ricks (Harlow, Essex: Longman, 19872), II, pp. 652-653 and III, pp. 7071. 
blessed than to put cares away, when the mind lays by its burden, and tired with labour of far travel we have come to our own home and rest on the couch we longed for? This it is which alone is worth all these toils. Welcome, lovely Sirmio, and rejoice in your master's joy, and you, ye waters of the Lydian lake, laugh out aloud all the laughter you have in your home. ${ }^{29}$

The comparison with the original shows that Smith's voice almost imperceptibly sneaks into the poem. She retains the basic idea - a traveler returns home to the peninsula Sirmio (at Lake Garda) after many deprivations abroad and addresses the island as if it were his badly missed lover - but makes a few changes. The most remarkable is the omission of the three last lines of the original, whereby the typical Catullan circle structure is lost and the personification of the peninsula is less prominent. While Catullus stresses the personification again in the end by telling the island to rejoice in his homecoming, and to burst into laughter, Smith only reproduces the vocative at the beginning.

A second element of change is the explicit way in which Smith distances herself from the learned elements in Catullus. The mysterious modification

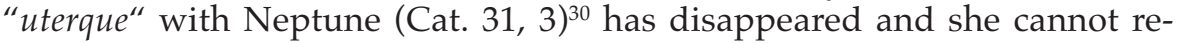
member the ingenious division of Bithynia in "Thynia atque Bithyni" (Cat. 31, 5) ${ }^{31}$ : "No sooner had I left Bithynia - and what was the name of the other place?" It is possible that Smith did not know that "Thynia atque Bithyni" refer to the same place and that Catullus uses this to preserve the duality throughout the poem. At the same time, this division is also a knowing wink to the reader. If Smith knew about the Catullan motives, her remark can be read as an ironic comment, as she does not feel like joining the intellectual games of the poetae docti.

Third, although Smith kept the basic idea, the content has slightly changed. In both poems the opposition between happiness and sorrow is dominant, but the outcome is different. In general, the accent in Smith's poem lies more on the sorrow due to the omission of the last three lines. Smith does not, like Catullus, end on a happy note, but stresses the pains one has to endure to have a home. Specifically, the translation of "videre te in tuto" demon-

29. Translated by Francis Warre Cornish, in Catullus, Tibullus and Pervigilium Veneris, second edition, revised by G. P. Goold, The Loeb Classical Library 6 (Cambridge: Harvard University Press - London: William Heinemann, 1988), pp. 36-37.

30. Classicists are still debating the exact meaning of "uterque" here. See e.g. Hans Peter Syndikus, Catull. Eine Interpretation. Erster Teil: Einleitung - Die kleinen Gedichte (1-60) (Darmstadt: Wissenschaftliche Buchgesellschaft, 1984), p. 188; Daniel H. Garrison, The Student's Catullus (Norman - London: University of Oklahoma Press, 1989), p. 111 and Phyllis Young Forsyth, The Poems of Catullus. A Teaching Text (Lanham - New York - London: University Press of America, 1986), p. 211. The modification probably belongs to the 'twofoldness' that characterizes the whole poem.

31. Both refer to the Roman province Bithynia in Asia Minor. Forsyth suggests that this is "more of a learned play on words than a serious question of ancient geography. Perhaps the doublet was poetically in keeping with the dual statements that permeate the poem" (Forsyth, The Poems of Catullus, p. 211; see also Garrison, The Student's Catullus, p. 111). 
strates the shifted accent. In Catullus, the traveler is safe when he reaches the island and is looking around, whereas in Smith, feeling safe and the sight of the island have nothing to do with each other: the traveler is already safe at sea and is at that point thinking of seeing the island again. Since the traveler was already safe at sea, the pleasure of arriving is less prominent. On top of that, with "safely at sea" Smith inserts a contradictio in terminis, and recovers with her phrasing of this contradiction the alliteration "te in tuto" of the Latin text.

As a final illustration of Smith's tendency to adapt the classical material to her own style, I wish to compare Smith's and Byron's versions of Hadrian's "Animula, vagula, blandula".

Animula vagula blandula
hospes comesque corporis,
quae nunc abibis in loca,
pallidula, rigida, nudula,
nec, ut soles, dabis iocos?

Adrian's address to his soul when dying 33

Ah! Gentle, fleeting, wav'ring sprite,

Friend and associate of this clay!

To what unknown region borne,

Wilt thou, now, wing thy distant flight?

No more, with wonted humour gay

But pallid, cheerless, and forlorn.

Animula, vagula, blandula

The Emperor Hadrian to his soul.

Little soul so sleek and smiling

Flesh's friend and guest also

Where departing will you wander

Growing paler now and languid

And not joking as you used to?

Smith probably first read the poem in Walter Pater's Marius the Epicurean, which starts its eighth chapter with the Latin original. ${ }^{34}$ We know for sure from her notebooks that she came across this book in 1919 and was deeply impressed by it. ${ }^{35}$ The poem proved to be a challenge for numerous translators,

32. Minor Latin Poets, eds./trans. J. Wight Duff - Arnold M. Duff, The Loeb Classical Library 284 (Cambridge: Harvard University Press - London: William Heinemann, 1978), p. 444.

33. Lord Byron, The Poetical Works of Lord Byron (London: Oxford University Press, 1930), p. 4.

34. Although in all of the editions of Pater's novel I have been able to check (London: Macmillan, 1893; ibidem, 1910 and London: J. M. Dent \& Sons LTD, 1960) the last line of Hadrian's poem is missing.

35. Spalding, Stevie Smith. A Biography (above, n. 3), pp. 41-43. 
in a variety of languages ${ }^{36}$, and caused a vivid academic debate. ${ }^{37}$ Byron's version seems to be quoted the most, although it is a work of youth and is considered to be one of the less successful attempts. ${ }^{38}$

Hadrian's poem deals with the contradiction between the position of the speaker (Hadrian) and that of his soul. We get an enumeration of how the soul is and how it will be. A tricky word in this opposition is "nudula" (naked, bare): apparently, neither Byron nor Smith knew what to do with this adjective. $^{39}$

Another element that stresses the contradiction between Hadrian and his soul is line three in Hadrian and Smith and lines three and four in Byron. Smith copies the idea of the uncertain destination of the soul by using the verb "to wander", a translation of "vagula", which she had omitted in her rendition of the opening line. Byron, however, focuses more on the different degrees of knowing between Hadrian and his soul by an internal contradiction: "unknown regions" (to Hadrian) opposite to "borne" (turn and proceed in a specific direction: action of the soul).

The style may provide us with a way to interpret the shifts in content. For Hadrian and Smith, the stress on the opposition is not so strong because of the dominant play with language. Due to the Latin system of declension, Hadrian is able to play with endings in " $-a$ ". Furthermore, there is the clever repetition of sounds in verse 2 ("hospes comesque corporis"). As the English language does not have such a declension system, the play with " $-a$ " is lost, but Smith tries to compensate for this by increasing the number of alliterations

36. In the late sixties and early seventies, more than one hundred translations were listed in a series of articles published in Hermeneus by various authors (with M. Rutgers van der Loef as instigator; see Hermeneus, 38 [1966-67], pp. 128-130, pp. 174-175, pp. 205-208; 41 [1969-70], pp. 69-71; 46 [1974-75], pp. 174-175, pp. 352357). The list was recently expanded by Diederik Burgersdijk, 'De ziel van keizer Hadrianus', Hermeneus, 76 (2004), pp. 304-314. Translations into English (at least ninety!), Dutch (more than ten), Italian, German, French, Polish, Scottish and ancient Greek have been traced. See also Patrick De Rynck (ed.), Op de snaren van Apollo. Acht eeuwen Latijnse poëzie (Baarn: Ambo, 1993), pp. 324-326 and the very rare Translations literal and free of the dying Hadrian's Address to his soul, collected and arranged by David Johnston (Bath: Printed at the "Chronicle" office, Kingston Buildings, 1876).

37. An element of discussion is the "quae" in v. 3 which can be understood as a relativum with "animula", or as an interrogative pronoun with "loca". The adjectives of v. 4 can be connected with "loca", but also with "animula" (both Byron and Smith opt for the second possibility). On top of that, we cannot be certain that Hadrian was the author of the poem (but the question of authorship has little to do with the way the poem appealed to translators and interpreters in the past centuries). For the debate on authorship, the transmission of the text and the various readings of the original, see Anthony R. Birley, 'Hadrian's Farewell to Life', Laverna, 5 (1994), pp. 176-205 and Carlo Gallavotti, 'Animula nudula', Maia. Rivista di Letterature Classiche, 23 (1971), pp. 297-302.

38. Birley, 'Hadrian's Farewell to Life', p. 177.

39. As some classicists, who did not know what to do with it either and proposed the emendation "nubila“; cf. Birley, 'Hadrian's Farewell to Life' (above, n. 37), p. 184. 
(verses $1,2^{40}$ and 3 ) which also may have suggested to her certain adjectives (v. 1). Finally, the light-footed cohesion in sound of Hadrian's poem is paralleled by Smith's quite successful trochaics.

Smith transposes the playfulness of the original to her own playful language and style. Byron, on the other hand, chooses another register and uses rhyme $(a b c a b c)$. The difference in register shifts the accent from a play with language to the content. The rhyme structure forces him to add an extra line (in which he further develops his interpretation of the opposition between Hadrian and his soul) and results in a different word-choice. As the alliteration forced Smith to translate "corporis" as "flesh", the rhyme structure in Byron's poem suggested "clay" (in order to rhyme with "gay"). Apart from the more biblical connotation, this has little effect on the interpretation, but the use of "associate" does. Since the number of syllables of each line had to be six, Byron could not choose "guest", but instead decided for "associate". In this, he loses the temporality of the situation of the guest which we find in the idea of the body as the host of our soul. ${ }^{41}$

Although Smith, according to her biographers, never had a formal education in Greek, she mastered the language well enough to read Homer and Euripides in the original later in life. ${ }^{42}$ She had a particular fondness for Euripides' Bacchae: not only did she incorporate (to the dislike of some readers ${ }^{43}$ ) a summary of the plot in her Novel on Yellow Paper ${ }^{4}$, but she also translated a small part. This surprisingly faithful rendition of verses 769-774 of Euripides' play is the only translation of a Greek text by Stevie Smith that I have been able to unearth, and it was never published during her lifetime, nor does it appear in her Collected Poems ${ }^{45}$ :

O Lord

From 2nd Messenger's Speech To King Pentheus, Bacchae

This god then, $\mathrm{O}$ lord whoever he is do receive into the city

For not only is he great but also as I have heard

40. The Collected Poems of Stevie Smith (above, n. 15) read "Flesh's friend and guest also" (p. 472), whereas Lee (ed.), Stevie Smith. A Selection (above, n. 4) has "Flesh's guest and friend also" (p. 164). We believe the first reading is more likely as here the alliteration in "comesque corporis" is preserved.

41. For the distinction between soul and body and the philosophical implications of Hadrian's poem, see: Emanuela Andreoni Fontecedro, 'Animula vagula blandula: Adriano debitore di Plutarco', Quaderni Urbinati di cultura classica, 55-1 (vol. 84 della serie continua, 1997), pp. 59-69.

42. Spalding, Stevie Smith. A Biography (above, n. 3), p. 43, p. 53 and p. 73.

43. See for instance the letter, written by Kenneth Clark (at that time president of the National Gallery) to Stevie Smith, and quoted in Barbera - McBrien, Stevie. A Biography of Stevie Smith (above, n. 3), p. 89: "I didn't like your summaries (or recreations, or whatever you call them) of the books \& plays you were reading. I know that a book is apt to play a great part in one's thoughts \& get muddled up with the emotions aroused by actual life: but even so, when it comes to writing out the plot of the Bacchae etc, it becomes rather a bore."

44. See Laura Severin, Stevie Smith's Resistant Antics (Madison, WI: University of Wisconsin Press, 1997), pp. 34-35 for a discussion of this summary.

45. Barbera - McBrien (eds.), Me Again. Uncollected Writings of Stevie Smith (above, $\mathrm{n}$. 1), p. 242. 
He gave the pain-killing vine to men.

Take away drink, where's Love?

Any pleasure come to that, $\mathrm{O}$ lord there is nothing left.

The discussion of these representative ways in which Stevie Smith incorporated Latin phrases, ancient myths and classical authors in her work, shows that she - in line with the non-conformism which marked her life - is not restrained by overzealous awe or an academic sense of correctness in making the traditional material her own. But attentive reading of the classical elements in her poetry also proves that genuine admiration and poetical technique are hiding under the cover of her "carefully contrived carelessness" ${ }^{46}$ Therefore, agreeing with classicist Armide Oppé, I can close with her judgement of Smith's relation to the classics: "She made great play with the little she knew, but knew it in a consuming way so that it really did become a part of herself." 47

46. Mark Storey, 'Why Stevie Smith matters', Critical Quarterly, 21-2 (1979), pp. 41-56, quote on p. 44.

47. Quoted by Spalding, Stevie Smith. A Biography (above, n. 2), p. 128. 
Copyright of International Journal of the Classical Tradition is the property of Springer Science \& Business Media B.V. and its content may not be copied or emailed to multiple sites or posted to a listserv without the copyright holder's express written permission. However, users may print, download, or email articles for individual use. 